\title{
Trisomy 14
}

National Cancer Institute

\section{Source}

National Cancer Institute. Trisomy 14. NCI Thesaurus. Code C116344.

A chromosomal abnormality consisting of the presence of a third copy of chromosome 14 in somatic cells. 